\title{
Influence of Geomorphology on Fish Fauna of a Small Mississippi Bluffline Stream
}

\author{
Scott Stephen Knight and Terry Douglas Welch \\ United States Department of Agriculture, Agricultural Research Service, National Sedimentation Laboratory, Oxford, MS 38655, USA
}

\begin{abstract}
Fish were collected from 39 sites on the main channel and major tributaries of a highly erosive stream, Hotophia Creek. A total of 2,642 specimens representing 38 species were collected between 1986 through 2003. The bluntface shiner Cyprinella camura was the dominant species of fish and when grouped with other cyprinids accounted for $38.0 \%$ of the total numbers collected. By weight, Lepisosteusoculatus, Lepomismegalotis, Ictiobusbubalus, and Lepomismacrochirus were the dominant species; accounting for $49.9 \%$ of the total catch. While more diminutive species such as cyprinids that might be subject to predation by large fish more frequently were found in shallow channels. Fishes with specific habitat requirement such as the pirate perch were found in the middle group of sites, that were disturbed by erosion process but that featured the necessary habitat requirements. Sensitive or intolerant species like the Yazoo darter, creek chubsucker and cyprinids in general were more frequently found in the undisturbed and habitat complex channels. This study supports the hypothesis that geomorphological stream stages are associated with specific communities of fishes.
\end{abstract}

Key words: Stream classification, geomorphology, index of biotic integrity, ecology.

\section{Introduction}

There are approximately 2.3 million streams comprising more than 5 million linear $\mathrm{km}$ in the continental United States [1]. These streams support at least $22 \%$ of all warmwater fishing in fresh water [2]. The majority of Mississippi anglers questioned in a state wide survey in 1986 stated that they preferred stream fishing, thus emphasizing the need for more information on the ecology and population dynamics of stream fishes to solve problems of increasing demand on warm water fisheries [3].

Few recent ichthyofauna records are available for northern Mississippi streams. Earlier surveys of area fishes were limited mainly to larger river systems.

Cook [4] studied several loess hill stream sites in her statewide survey. Other collections include the Tippah River system by Randolph and Kennedy [5], and upper Tombigbee River and Yellow Creek by Caldwell [6], Toby Tubby Creek and Clear Creek by Herring [7], Longbranch Creek, Billy's Creek, and

Corresponding author: Scott Stephen Knight, research ecologist, Ph.D., main research fields: fisheries biology and aquatic ecology.E-mail: scott.knight@ars.usda.gov.
Otoucalofa Creek by Hammond [8] and Otoucalofa Creek by Knight and Cooper [9].

Since Hotophia Creek, Mississippi was included in a major stream management program (Demonstration Erosion Control (DEC) Project in the Yazoo Basin) by the U.S. Army Corps of Engineers and the Natural Resources Conservation Service, information on the fish populations of Hotophia Creek was collected to evaluate stream conditions and the environmental soundness of structural and non-structural erosion control efforts. The purpose of this study was to examine effects of geomorphological conditions on diversity, distribution and population dynamics of the fish fauna of Hotophia Creek.

\section{Materials and Methods}

Hotophia Creek in Panola County, Mississippi (Fig. 1) enters the Little Tallahatchie River downstream of Sardis Lake. Its catchment basin was 8,500 ha, of which $24 \%$ were row crops and $14 \%$ were pastures. The remainder of the watershed was primarily forest land. Like many streams along the bluffline, Hotophia Creek was characterized by a bottom substrate of sand 


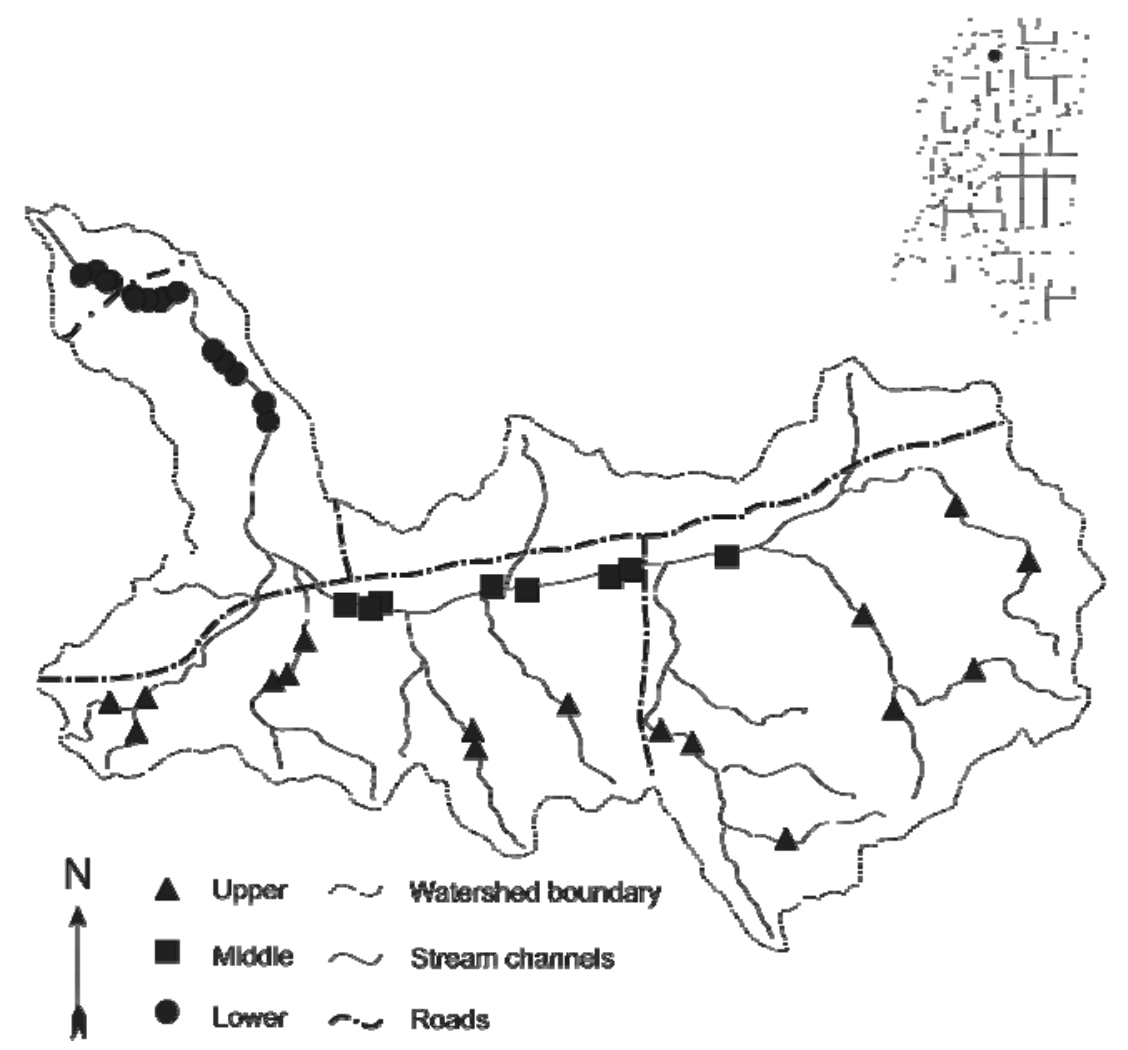

Fig. 1 Fish collection sites on Hotophia Creek, Mississippi.

with slow to moderate flow in an open channel with no canopy at its confluence with the Little Tallahatchie River. The channel gradually narrows and deepens, changes to clay, and had a nearly total coverage of canopy at its head waters. There were virtually no aquatic macrophytes because of the unstable nature of the stream channel. Watersheds in the loess hills of northern Mississippi were chosen as the sites of both structural and non-structural erosion control and stabilization efforts because they have a history of large scale erosional sequences with massive gully formation and large soil losses from agricultural lands. Hotophia Creek, a tributary of the Tallahatchie River was included in the six original watersheds for the project.

Fish were collected from 39 sites each consisting of stream reaches 100 to $200 \mathrm{~m}$ long. Sites were sorted into one of three groups which included aggrading channels (Lower), located near the distal end of the watersheds, mid-watershed sites (Middle) and tributaries and head water channels (Upper). The lower channel group of sites roughly corresponds to Type VI channels as designated by Simon [10] and Bledsoe et al. [11] models of channel evolution. These channels feature developed berms of sand, gravel or mud. They are aggrading or in quasi-equilibrium. Habitat is characterized by uniform velocities, fine bed material and deeper water depths. No pool habitat or large woody debris is present. Middle sites, corresponding to Type IV and V channels [10,11] exhibit channel widening due to bank failure and may be aggrading or degrading. Large woody debris may be scarce and banks typically lack riparian vegetation. Channel beds are composed primarily of shifting sand. Habitat is highly disturbed and characterized by uniform velocities and shallow depths. The thalweg moves back and forth laterally within the banks with each major storm event. Upper sites were either undisturbed and stable or moderately disturbed due to channel incision caused by migration of head cuts. Banks were heavily vegetated with trees and riparian plants. Large woody debris was abundant. Depths and 
velocities were heterogeneous with riffle pool sequences. Bed materials varied between combinations of sand, gravel, hard clay and leaf litter. These channels correspond to Type I or II $[10,11]$.

Fish were collected using a battery powered, backpack mounted electroshocker set for 200 to 400 volts of pulsed direct current. Current was pulsed at $150 \mathrm{pulses} / \mathrm{sec}$. Voltage was varied depending upon the conductivity of the water. Larger and easily identifiable specimens were weighed and measured for length in the field, then released. Small specimens or those which could not be positively identified in the field were preserved in $10 \%$ formalin solution and transported to the laboratory for identification and measuring. Preserved materials were deposited in the National Sedimentation Laboratory Reference Collection or at the Mississippi Museum of Natural Sciences.

\section{Results and Discussion}

A total of 2,642 fish representing 38 species were collected from 39 sites on Hotophia Creek. Total weight collected from these 39 sites was $11.7 \mathrm{~kg}$ Catch per unit of effort was $3.31 \mathrm{~kg} / \mathrm{hr}$ for all species and site groups while number per unit of effort was $420 \mathrm{fish} / \mathrm{hr}$ The most frequently caught species were Cyprinella camura, Cyprinella venusta, Lepomis megalotis, Lepomis macrochirus, and Fundulus notatus with all found in each of the site groups (Table 1). Spotted gar, Lepisosteus oculatus accounted for $13.7 \%$ of the total weight of fish collected but only represented $0.68 \%$ of the catch by number. Lepomis megalotis, Ictiobus bubalus, Lepomis macrochirus and Cyprinella camura contributed $12.9 \%, 12.5 \%, 10.8 \%$ and $7.6 \%$ to the total weight respectively.

Lower and middle channel sites were dominated numerically by Lepomismegalotis, Pimephalesnotatus, Lepomismacrochirus,

Cyprinellavenusta, andFundulusnotatus (Fig. 2) while in upper sites Notropisrafinesquei replaced bluegill in the list of the dominant five species. By weight, Lepomismacrochirus and Lepomismegalotis were among the five dominant species across the three categories of stream channels in Hotophia Creek watershed (Fig. 3). In addition to these two sunfishes, spotted gar, Lepisosteusoculatus, smallmouth buffalo, Ictiobusbubalus, and channel catfish, Ictalurus punctatus accounted for $65 \%$ of the catch by weight from the lower stream reaches. The afore mentioned sunfishes along with spotted gar, bluntface shiners, Cyprinellacamura, and creekchub suckers, Erimyzon oblongus comprised $64 \%$ of the catch in middle reaches. The same species found in the middle reaches, with the exception of spotted gar which did not occur in the upper channel group, dominated the catch and with the addition of green sunfish, accounted for $54 \%$ of the catch by weight. Average catch per unit of effort was highest in the lower group of sites $(5.15 \mathrm{~kg} / \mathrm{hr})$, followed by upper $(2.12 \mathrm{~kg} / \mathrm{hr})$ and middle $(1.98 \mathrm{~kg} / \mathrm{hr})$ channels while number per unit of effort was higher in the upper channels (486 fish/hr), followed by lower (458 fish/hr) and middle (289 fish $/ \mathrm{hr}$ ) reaches. Intolerant species $[12,13]$ comprised a greater percentage of the catch in the upper group, $16.7 \%$, versus $11.1 \%$ for middle and $7.1 \%$ for lower groups of sites.

Fourteen species were found across all site groups. As might be expected, four species, all of which attain a larger adult size were unique to the lower channel group including Ictiobusbubalus, Ictiobusniger, Lepisosteusosseus and Pylodictisolivaris Gizzard shad. Dorosomacepedianum was also found exclusively in the lower channel group. While these fish seldom reach lengths greater than $521 \mathrm{~mm}$ gizzard shad are filter feeders requiring deeper more quiescent waters capable of supporting plankton [14].

Golden shiner, Notemigonuscrysoleucas, warmouth, Lepomisgulosus and pirate perch, Aphredoderussayanus were only found in the middle group of stream channels. Species unique to the upper group included: Etheostomaraneyi, Micropterussalmoides, Notropisatherinoides and Ameiurus nebulosus; all except for the M. salmoides are relatively diminutive as adults. 
Table 1 Number of individuals caught and frequency of occurrence with in stream category by species from Hotophia Creek, Panola Co., MS.

\begin{tabular}{|c|c|c|c|c|c|}
\hline & & & & Category & \\
\hline Scientific name & Common name & Number caught & Upper & middle & Lower \\
\hline Aphredoderussayanus & Pirate perch & 2 & & 2 & \\
\hline Labidesthessicculus & Brook silverside & 8 & & 4 & 4 \\
\hline Carpiodescarpio & River carpsucker & 13 & & 3 & 10 \\
\hline Ictiobusbubalus & Smallmouth buffalo & 18 & & & 18 \\
\hline Ictiobusniger & Black buffalo & 1 & & & 1 \\
\hline Moxostomapoecilurum & Blacktail redhorse & 7 & 1 & 3 & 3 \\
\hline Erimyzon oblongus & Creek chubsucker & 36 & 29 & 7 & \\
\hline Lepomiscyanellus & Green sunfish & 144 & 78 & 21 & 45 \\
\hline Lepomisgulosus & Warmouth & 2 & & 2 & \\
\hline Lepomishumilis & Orange spotted sunfish & 17 & 13 & 4 & \\
\hline Lepomismacrochirus & Bluegill & 282 & 59 & 50 & 173 \\
\hline Lepomismarginatus & Dollar sunfish & 9 & 2 & 5 & 2 \\
\hline Lepomismegalotis & Longear sunfish & 343 & 57 & 100 & 186 \\
\hline Micropteruspunctulatus & Spotted bass & 46 & 6 & 17 & 23 \\
\hline Micropterussalmoides & Largemouth bass & 1 & 1 & & \\
\hline Dorosomacepedianum & Gizzard shad & 21 & & & 21 \\
\hline Cyprinellacamura & Bluntface shiner & 490 & 227 & 92 & 171 \\
\hline Cyprinellalutrensis & Red shiner & 43 & 1 & 6 & 36 \\
\hline Cyprinellavenusta & Blacktail shiner & 376 & 161 & 79 & 136 \\
\hline Notemigonuscrysoleucas & Golden shiner & 1 & & 1 & \\
\hline Notropisatherinoides & Emerald shiner & 3 & 3 & & \\
\hline Notropisrafinesquei & Yazoo shiner & 178 & 126 & 5 & 47 \\
\hline Pimephalesnotatus & Bluntnose minnow & 34 & 13 & & 21 \\
\hline Pimephalesvigilax & Bullhead minnow & 59 & 1 & & 58 \\
\hline Semotilusatromaculatus & Creek chub & 8 & 7 & 1 & \\
\hline Fundulusnotatus & Blackspotted topminnow & 247 & 94 & 35 & 118 \\
\hline Fundulusolivaceus & Blackstripe topminnow & 50 & 8 & 31 & 11 \\
\hline Ameiurusnatalis & Yellow bullhead & 33 & 24 & 7 & 2 \\
\hline Ameiurus nebulosus & Brown bullhead & 1 & 1 & & \\
\hline Noturusphaeus & Brown madtom & 15 & 11 & 4 & \\
\hline Ictalurus punctatus & Channel catfish & 30 & & 2 & 28 \\
\hline Pylodictisolivaris & Flathead catfish & 2 & 2 & & \\
\hline Lepisosteusoculatus & Spotted gar & 9 & & 2 & 7 \\
\hline Lepisosteusosseus & Longnose gar & 1 & & & 1 \\
\hline Etheostomaartesiae & Red spotted darter & 4 & 2 & 2 & \\
\hline Etheostomaraneyi & Yazoo darter & 3 & 3 & & \\
\hline Percinasciera & Dusky darter & 13 & 3 & 5 & 5 \\
\hline Gambusiaaffinis & Mosquito fish & 92 & 26 & 19 & 47 \\
\hline
\end{tabular}

The Yazoo shiner, Notropisrafinesquei was found in all groups but was most abundant in shallow sand bed channels of upper watershed sites. Cyprinids were commonly collected at all sites but were most abundant in the upper group. There were seven species of cyprinids in the upper group versus six at the lower and middle reaches. Twice the number of cyprinids were collected from undisturbed upper sites versus more geomorphologically unstable middle sites. Pirate perch, found in the middle reaches, require habitats that feature undercut banks with tangled fine roots. Many of the sites in the middle group were 


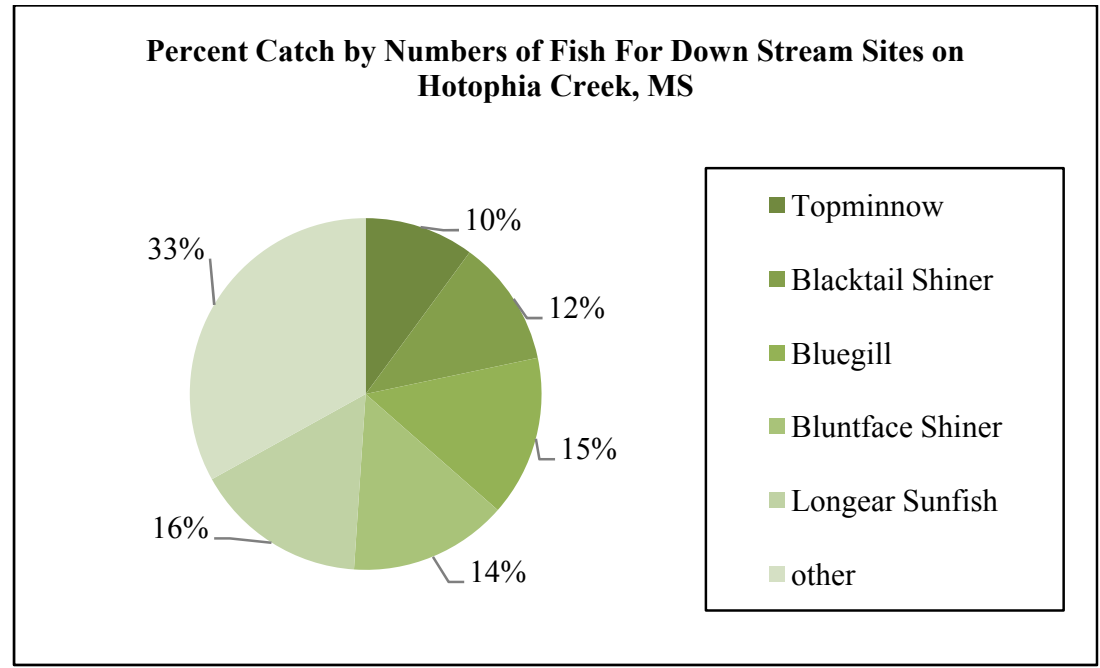

(a)

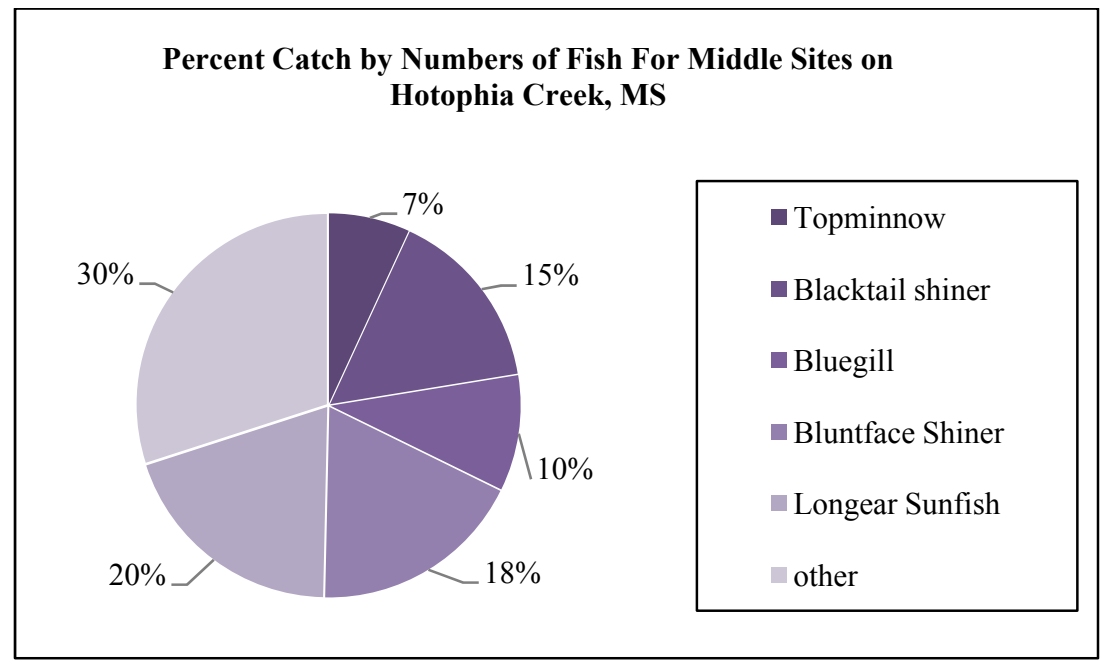

(b)

Percent Catch by Numbers of Fish For Up Stream Sites on Hotophia Creek, MS

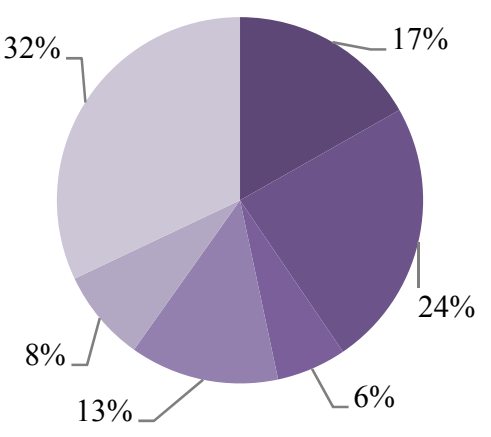

- Blacktail shiner

Bluntface Shiner

Bluegill

- Yazoo Shiner

Longear sunfish

other

(c)

Fig. 2 Percent composition by number of fish collected from Hotophia Creek, Mississippi: (a) down stream sites, (b) middle sites, (c) up stream sites. 


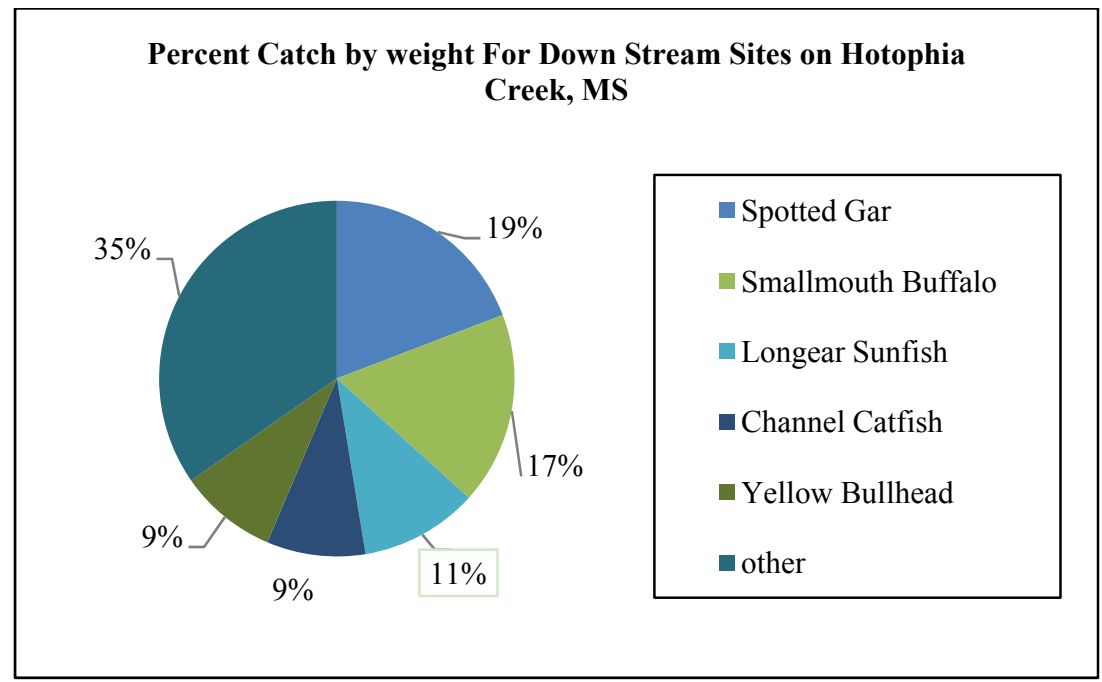

(a)

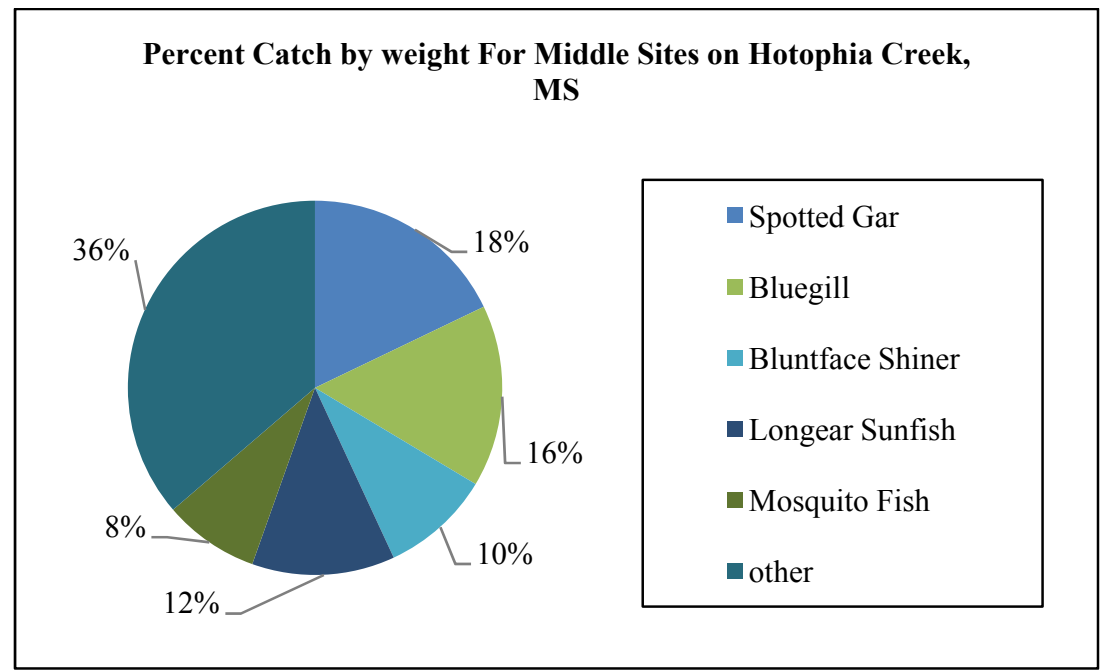

(b)

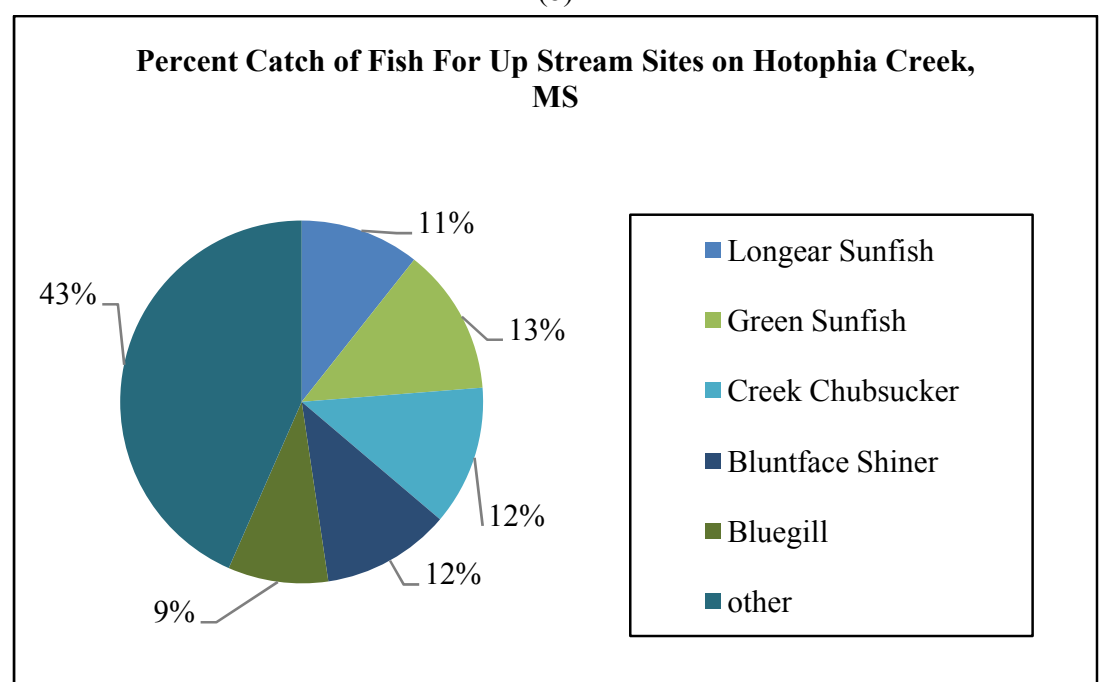

(c)

Fig. 3 Percent composition by weight of fish collected from Hotophia Creek, Mississippi: (a) down stream sites, (b) middle sites, (c) up stream sites. 
actively incising and thus providing the preferred habitat of pirate perch.

Two of the 38 species found in Hotophia Creek, Etheostomaraneyi and Ictiobusniger are listed as species of "Special Concern" by the State of Mississippi and the American Fisheries Society [14, 15]. Special concern status is for those species recognized by state conservation agencies as (1) declining in numbers or distribution but not yet warranting full protection by law or (2) taxa about which too little in known to determine if they are in need of protection. The Yazoo darter has been reported in several northern Mississippi streams [5, 9, 16, 17]. Although the Hotophia Creek collections represent a westward extension of its assumed range, the few individuals collected tend to indicate a remnant populationor loss of critical habitat.

\section{Conclusions}

Fishes fauna recovered from Hotophia Creek did not differ greatly from those reported in faunal lists from other streams in the loess bluff and central hills of northern Mississippi [9]. Therefore, conclusions based on this study may apply generally to other loess bluff and central hill watersheds. A major assumption of various ecological indices such as Index of Biotic Integrity (IBI) is that water quality and habitat features determine the relative abundance and distribution of fishes in stream watersheds [18]. This study supports the hypothesis that habitat features are important determining factors in the distribution of stream fishes. Simon and Rinaldi [19] reported that the geomorphological processes following channel straightening progress through definable stages. This study shows that these stages are associated with specific communities of fishes.

Fish species attaining large adult sizes such as buffalo and gar were associated with stream types that containeddeeper water habitats. While more diminutive species such as cyprinids that might be subject to predation by large fish more frequently were found in shallow channels. Fishes with specific habitat requirement such as the pirate perch were found in the middle group of sites, comprised of Type IV and V channels and that featured the necessary habitat requirements. Sensitive or intolerant species like the Yazoo darter, creek chubsucker and cyprinids in general were more frequently found in the undisturbed and habitat complex Type I and II channels. While IBI and other indices are valuable tools and may be useful surrogates for estimating impact of poor water quality in impaired streams, caution should be exercised because presence or absence of habitat features may over shadow water quality effects.

\section{Acknowledgements}

The authors wish to thank personnel from the Agricultural Research Service, the Natural Resources Conservation Service (NRCS), and the U.S. Army Corps of Engineers (COE). The COE provided cooperative funding and NRSC provided necessary landowner and site information. Special appreciation goes to Sam Testa, Belinda Garroway, Jennifer Bowen, Michelle Malott, Cliff Dew, and Matt Gray for their help during various stages of this project.

\section{References}

[1] Lime, David, W. 1983. Water, Water Everywhere-for Americans at Play. U.S.: Dept. of Agriculture.

[2] U.S. Fish and Wildlife Service and U.S. Census Bureau. 2012. 2011 National Survey of Fishing, Hunting, and Wildlife-associated Recreation. U.S.: Fish and Wildlife Service and Census Bureau.

[3] Miranda, L. E. and Frese, W. 1987. A Survey of the Recreational Fishery Desires of Mississippi Licensed Anglers. Mississippi: Mississippi Department of Wildlife Conservation.

[4] Cook, F. A. 1959. Freshwater Fishes in Mississippi. Mississippi: Miss. Game and Fish Comm.

[5] Randolph, K. N. and Kennedy, M. L. 1974. "The Fishes of the Tippah River System, Mississippi with Notes on Habitats and Distribution." J. Miss. Acad. Sci. 19: 128-134.

[6] Caldwell, R. D. 1969. "A Study of the Upper Tombigbee River and Yellow Creek Drainage Systems of Alabama and Mississippi." Unpublished Ph.D. Dissertation, 
University of Alabama.

[7] Herring, A. J. 1966. "Distribution of the Fishes of Toby Tubby Creek and Clear Creek Tributaries of Sardis Reservoir. Unpub.” M.S. thesis, University of Mississippi.

[8] Hammond, R. A. 1970. "A Study of Fish Fauna Indigenous to Three Creeks in Yalobusha County Mississippi. Unpub." M.S. thesis, University of Mississippi.

[9] Knight, S. S. and Cooper, C. M. 1987. "Fishes of Otoucalofa Creek, Mississippi Prior to Major Channel Modifications." J. Miss. Acad. Sci. 32: 31-338.

[10] Simon, A. 1989. "A Model of Channel Response in Disturbed Alluvial Channels." Earth Surface and Landforms 14: 11-26.

[11] Bledsoe, B. P., Watson, C. C. and Biedenharn, D. S. 2002. "Quantification of Incised Channel Evolution and Equilibrium." Journal of the American Water Resources Association. 38 (3): 861-870.

[12] Emery, E. B., Simon, T. P., McCormick, F. H., Angermeier, P. L., Deshon, J. E., and Yoder, C. O. et al. 2003. "Development of a Multimetric Index for Assessing the Biological Condition of the Ohio River. Trans." Am. Fish. Soc. 132: 791-808.

[13] Jester, D. B., Echelle, A. A., Matthews, W. J., Pigg, J.,
Scott, C. M., and Collins, K. D. 1992. "The Fishes of Oklahoma, Their Gross Habitats, and Their Tolerance of Degradation in Water Quality and Habitat." Proc. Okla. Acad. Sci. 72: 7-19.

[14] Ross, Stephen T. 2001. Inland Fishes of Mississippi. Mississippi: University of Mississippi Press.

[15] Johnson, James E. 1987. Protected Fishes of the United States and Canada. Bethesda: Am. Fish. Soc..

[16] Clemmer, G. H., Suttkus, R. D., and Ramsey, J. S. 1975. "A Preliminary Checklist of Endangered and Rare Fishes of Mississippi." In Preliminary List of Rare and Threatened Vertebrates in Mississippi. Edited by Jackson, M. S. Mississippi: Miss. Game and Fish Comm..

[17] Douglas, N. H. 1975. Survey of Endangered, Threatened, Peripheral, Status Undetermined and Unique Fish Species of Holly Springs National Forest, Mississippi. Atlanta: Report to Southeast, Region, U. S. Forest Service.

[18] Karr, J. R. 1981. "Assessment of Biotic Integrity Using Fish Communities." Fisheries (Bethesda) 6: 21-27.

[19] Simon, A., and Rinaldi, M. 2006. "Disturbance, Stream Incision, and Channel Evolution: The Roles of Excess Transport Capacity and Boundary Materials in Controlling Channel Response." Geomorphology 79: 361-383. 